\title{
Nutrition of liver transplant patients
}

\author{
Arved Weimann $\mathrm{MD}^{1}$, Mathias Plauth $\mathrm{MD}^{2}$, Stefan $\mathrm{C}$ Bischoff $\mathrm{MD}^{3}$, Ernst R Kuse MD ${ }^{1}$
}

\begin{abstract}
A Weimann, M Plauth, SC Bischoff, ER Kuse. Nutrition of liver transplant patients. Can J Gastroenterol 2000;14(Suppl D): 85D-88D. Good cooperation between the hepatologist, surgeon and anesthesiologist is required to determine the appropriate perioperative nutritional management for the liver transplant patient. For preoperative risk stratification, nutritional assessment according to resting energy expenditure by indirect calorimetry, and body cell mass by bioelectrical impedence analysis, may be superior to anthropometric parameters. When considering impaired glucose tolerance in the early postoperative period, requirements of energy intake and macronutrients are no different from those established in major abdominal surgery. Preference should be made to use the enteral route whenever possible. Fat emulsions containing medium-and long-chain triglycerides have neither a negative impact on reticulo-endothelial system recovery of the graft, nor any obvious metabolic advantages. There is no evidence for the routine use of branched-chain amino acids. Even in the case of good graft function, long term dietary evaluation and counselling may be useful. Impaired glucose tolerance, hyperlipidemia and hypercholesterolemia should be considered carefully. The role of preoperative nutritional therapy using oral supplements and the value of immune-enhancing substrates should be evaluated with special regard to a decrease in postoperative septic complications and for possible impact on immune tolerance after transplantation.
\end{abstract}

Key Words: Energy requirement; Enteral nutrition; Liver transplantation; Parenteral nutrition; Perioperative nutrition

\section{La nutrition chez les greffés du foie}

RÉSUMÉ : Il faut une bonne coopération entre l'hépatologue, le chirurgien et l'anesthésiste pour déterminer quel sera le traitement nutritionnel approprié chez le greffé du foie. Pour la stratification du risque préopératoire, l'évaluation nutritionnelle periopératoire calculée en fonction des dépenses énergétiques au repos mesurées par calorimétrie indirecte et de la masse cellulaire de l'organisme mesurée par analyse de l'impédance bioélectrique pourrait être préférable aux paramètres anthropométriques. Lorsque l'on tient compte de l'intolérance au glucose au cours de la période postopératoire immédiate, les exigences énergétiques et en macronutriments ne diffèrent pas de celles qui sont fixées pour une intervention abdominale majeure. On préférera la voie entérale dans la mesure du possible. Les émulsions graisseuses renfermant des triglycérides à chaîne intermédiaire et longue n'exercent pas d'impact négatif sur le rétablissement du système réticulo-endothélial du greffon et n'offrent aucun avantage métabolique clair. Rien ne milite en faveur de l'utilisation d'emblée d'acides aminés à chaîne ramifiée même dans le cas du bon fonctionnement du greffon, une évaluation et un counselling diététiques à long terme pourraient être utiles. Il faut tenir compte de l'intolérance au glucose, de l'hyperlipidémie et de l'hypercholestérolémie. Le rôle du traitement nutritionnel préopératoire à l'aide de suppléments oraux et l'utilité de substrats stimulant l'immunité doivent être évalués et une attention particulière doit être accordée à la prévention des complications septiques postopératoires et à un impact possible sur l'immunotolérance après la transplantation.
$\mathrm{N}$ utritional status has been shown to be an important prognostic factor in patients with end-stage liver disease undergoing liver transplantation (1-7). In these patients, malnutrition may be related to poor nutritional intake, malabsorption and liver disease itself. Muscle wasting, fat store depletion, impaired immunological function, and decreased vitamin and trace element serum levels may influence patient outcome by prolonging catabolic state, increasing risk of septic complications, and causing long term weaning and intensive care unit stay $(8,9)$. However, there are no detailed clinical guidelines and recommendations with regard to the perioperative nutrition of the liver transplant patient. Only limited data from controlled studies are available, which may well be attributed to transplant units placing a

This article was prepared from a presentation made at the World Congress of Gastroenterology, Vienna, Austria, September 6 to 11, 1998

${ }^{1}$ Klinik für Abdominal- und Transplantationschirurgie, Medizinische Hochschule Hannover; ${ }^{2}$ Medizinische Klinik mit Schwerpunkt

Gastroenterologie/Hepatologie und Endokrinologie, Charité, Humboldt-Universität zu Berlin; ${ }^{3}$ Abteilung Gastroenterologie und Hepatologie,

Medizinische Hochschule, Hannover, Germany

Correspondence and reprints: Dr Arved Weimann, Klinik für Allgemein- und Visceralchirurgie, Stafdtisches Klinikum "St Georg", Delitzscher Str 141,

04129 Leipzig, Germany. Telephone +49-341-909-2200, fax +49-341-909-2234, e-mail st.georg-leipzig@t-online.de

Received for publication January 28, 1999. Accepted February 5, 1999 
TABLE 1

Identification of high risk liver transplant candidates

\begin{tabular}{ll}
\hline Assessment & Reference \\
\hline $\begin{array}{l}\text { Subjective global assessment } \\
\text { Anthropometric measurements }\end{array}$ & Pikul et al (7), Hasse et al (13) \\
\multicolumn{1}{c}{ Midarm circumference } & Harrison et al (6) \\
Triceps skin fold & DiCecco et al (9) \\
$\quad \begin{array}{l}\text { Children: Z-score }\left(\mathrm{x}-\mathrm{x} / \mathrm{SD}_{\mathrm{X}}\right) \\
\text { height and weright }\end{array}$ & $\begin{array}{l}\text { Moukarzel et al (3) } \\
\text { Roggero et al (5) }\end{array}$ \\
$\begin{array}{l}\text { Indirect calorimetry } \\
\text { Resting energy expenditure } \\
\text { (increase }>20 \%)\end{array}$ & Selberg et al (4) \\
Bioelectrical impedance analysis & \\
Body cell mass (BCM <35\% BW) & Selberg et al (4) \\
\hline
\end{tabular}

BW Body weight

higher priority on prospective clinical trials investigating immunosuppressive drugs. This review presents the available data from prospective randomized controlled trials (A); welldesigned, nonrandomized, prospective retrospective studies (B); and the clinical practice in 16 experienced European transplant units that was evaluated by a questionnaire in 1996 (10) and the consensus statement of the European Society for Parenteral and Enteral Nutrition and Metabolism (ESPEN) (11) (C).

\section{MALNUTRITION AS A RISK FACTOR}

To improve the outcome of liver transplantation, it has been proposed that candidates should be selected according to nutritional state (3). However, the European questionnaire reveals an agreement that a bad nutritional state per se reflects the severity of liver disease but should not be considered a reason to exclude candidates (10). Several authors have suggested criteria to identify candidates at high risk (B) (Table $1)$ : subjective global assessment $(7,12,13)$; anthropometric parameters $(5,6,9)$; and resting energy expenditure and body cell mass as determined by bioelectrical impedance analysis (4). For hypermetabolism and reduced body cell mass, a direct correlation with survival after transplantation could be shown, while ascites, clinical edema and the Child-Pugh score had no prognostic value (4). Although risk stratification is possible, most transplant units have no standardized pretransplant nutritional protocol (10). To date, only one prospective controlled trial has focused on the possible benefit of supplemented nutrition before transplantation. Chin et al (14) performed a crossover study in 19 children, administering nasogastric infusions with a branched-chain, amino acid (BCAA)-enriched formula versus an isonitrogenous and isocaloric standard formula for 28 days. In the BCAA group, there was a significant improvement in weight and height, an increase in mean arm circumference and subscapular skinfold thickness, and an increase in total body potassium, while no significant changes were observed in the control group. Clearly, these data demonstrate that nutritional status can be improved before transplantation, at least in children (A).

\section{EARLY POSTOPERATIVE PERIOD}

In the early postoperative period, graft function is primarily related to donor conditions and preservation and/or reperfusion injury. Graft steatosis is common and is accompanied by disturbances in energy metabolism. Glucose oxidation and the tricyclic acid cycle may be inhibited. Ketogenesis is not accelerated, although more free carnitine is produced $(15,16)$. Regarding substrate utilization, impaired glucose tolerance should be expected. Therefore, early administration of lipids is recommended (B) (15).

Reilly et al (17) demonstrated the value of postoperative total parenteral nutrition (TPN) by comparing no support versus isocaloric and isonitrogenous TPN with standard amino acids and BCAA, respectively. TPN patients had a significantly better nitrogen balance and a shorter length of stay in the intensive care unit (A). Wicks et al (18) prospectively compared enteral feeding and TPN. Enteral nutrition was started within $18 \mathrm{~h}$ after transplantation via nasojejunal tubes. No difference was shown concerning anthropometric parameters, intestinal function and infectious complication rate, and the authors concluded that enteral feeding was just as effective at maintaining nutritional status as TPN (A). Hasse et al (19) found beneficial effects of early enteral nutrition comparing enteral nutrition versus parenteral electrolyte solutions (A). While the nonisocaloric regimen has to be discussed critically, the nitrogen balance was significantly better on postoperative day 4 in the tubefed group. Furthermore, viral infections occurred in $17.7 \%$ of control patients compared with none of the tube-fed patients $(\mathrm{P}<0.05)$. No difference was found for resting energy expenditure, overall infection rate, rejection rate, hours on the ventilator, length of stay in intensive care unit or hospital, hospital costs and rehospitalization rate. In common practice, most transplant units perform a combination of parenteral and enteral nutrition (C). Nasoduodenal and nasojejunal tubes are preferred for the enteral route (C). Pescovitz et al (20) retrospectively showed in 108 patients that jejunostomy tubes can be safely placed during transplantation, carrying a low risk for serious complications (B). Nevertheless, complications occurred in 16 patients (14.8\%) and resulted in six laparotomies.

Plevak et al (21) prospectively investigated caloric and protein requirements. No increase of resting energy expenditure above preoperative values was found. However, there was a persistent catabolic state, with a significant increase of urinary nitrogen and 3-methyl-histidine excretion after transplantation, and a negative nitrogen balance up to postoperative day 28 . Therefore, caloric intake using the Harris-Benedict equation at ideal body weight plus $20 \%$, and $1.2 \mathrm{~g}$ protein/kg of body weight/day, was recommended (B). This is in line with the common practice in European transplantation units. Many centres prefer BCAA-enriched amino acid solutions as well as fat emulsions containing mediumchain triglycerides (MCT) and long-chain triglycerides 
TABLE 2

Nutritional support of the liver transplant patient - Consensus recommendations of the European Society for Parenteral and Enteral Nutrition and Metabolism (10)

\begin{tabular}{|c|c|}
\hline Postoperative period & Nutritional requirement \\
\hline \multicolumn{2}{|l|}{ Early } \\
\hline Nonprotein energy requirement & Use Harris-Benedict equation by ideal body weight plus $20 \%$ to $30 \%$ \\
\hline Nonprotein calories ratio & $50 \%$ to $60 \%$ glucose: $40 \%$ to $50 \%$ fat; avoid insulin \\
\hline Protein requirement & 1.0 to $1.5 \mathrm{~g} / \mathrm{kg}$ of body weight/day; no clear advantage of BCAA \\
\hline Electrolytes & $\begin{array}{l}\text { Caution: pontine myelinolysis due to rapid correction of chronic hyponatremia; cyclosporine- and } \\
\text { tacrolimus-induced hypomagnesemia }\end{array}$ \\
\hline Vitamins and trace elements & No published trials: combined supplementation daily \\
\hline Monitoring & Serum: glucose, electrolytes, lactate, triglycerides, urea; urine: urea excretion \\
\hline \multicolumn{2}{|l|}{ Late } \\
\hline Monitoring for diabetes & Diabetic potential of tacrolimus greater than cyclosporine; improvement of glucose metabolism by dose reduction \\
\hline $\begin{array}{l}\text { Monitoring for hyperlipidemia } \\
\text { and hypercholesterolemia }\end{array}$ & Changes in cholesterol metabolism, correlation with cyclosporine serum levels: dietary limitations \\
\hline Obesity & Dietary counselling; physical activity \\
\hline
\end{tabular}

BCAA Branched-chain amino acids. Data from reference 10

(LCT). With regard to the use of BCAA, no significant advantage was found by Reilly et al (17) versus standard amino acids (A). Kuse et al (22) measured postoperative reticuloendothelial system function and showed that fat emulsions containing MCT and LCT have no negative impact on reticulo-endothelial system recovery (A). Recently, Delafosse et al (23) compared administration of LCT versus MCT and LCT. The results from indirect calorimetry and isotopic labelling with ${ }^{13} \mathrm{CO}_{2}$ and ${ }^{13} \mathrm{C}$ plasma glucose could not prove a clear-cut advantage of MCT and LCT, with regard to lipid oxidation (A). No data from published trials exist with regard to the supplementation of immunomodulating substances, either on the parenteral or enteral route. Most European transplant units reported that they lack appropriate experience and some are concerned about the potential negative influence on graft rejection.

When supplementing electrolytes for chronic hyponatremia, there should be cautious adjustments of not more than $10 \mathrm{mmol} / \mathrm{L}$ per day, because of the risk of pontine myelinolysis (24) (C). Cyclosporine- or tacrolimus-induced hypomagnesemia has to be considered (25) (A). While most transplant units supply parenteral nutrition - supplemented with vitamins and trace elements $(\mathrm{C})$ according to general recommendations - no precise and specific suggestions can be made from the available clinical data.

According to the ESPEN consensus (Table 2), metabolic monitoring should include assessment of serum glucose, lactate, triglycerides and urea, as well as urine urea excretion (C). Indirect calorimetry may be used as a facultative tool. Hyperglycemia may be tolerated to a serum level no higher than 180 to $200 \mathrm{mg} / 100 \mathrm{~mL}$ (C). As a general rule, a reduction in infusion rate is preferable to increasing insulin administration. According to the results of the ESPEN survey, postoperative nutritional support is performed for a median of three to five days, with a maximum of 20 days and more. In case of Rouxen-Y bile duct anastomosis, oral and/or enteral feeding via a nasoduodenal tube usually starts no earlier than postoperative day 5 or $6(\mathrm{C})$.

\section{LATE POSTOPERATIVE PERIOD}

Surprisingly, few data are available on body composition and substrate metabolism in patients after successful liver transplantation. Protein turnover seems to decrease but is not normalized 12 months after transplantation (26). At that time, there is an increase in body fat but still no increase in body cell mass (27). While no specific dietary measures are necessary in the case of uneventful progress, metabolic monitoring should focus on impaired glucose tolerance, hyperlipidemia, hypercholesterolemia and obesity. Some immunosuppressive drugs potentially lead to diabetes - tacrolimus being more harmful than cyclosporine. Significant improvement of glucose metabolism and insulin secretion has been achieved by a dose reduction of tacrolimus to trough levels of 3 to $8 \mathrm{ng} / \mathrm{mL}$ (28) (B). Obesity before transplantation reliably predicts obesity after transplantation. The extent of obesity does not correlate with hypercholesterolemia (29). Hyperlipidemia and hypercholesterolemia are very common and may be correlated with cyclosporine A serum levels. Therefore, these phenomena may be attributed more to specific changes in energy expenditure and cholesterol metabolism than to exogenous dietary factors (30). Chronic impairment of graft function may be related to diminished arterial perfusion, recurrent cholangitis or chronic rejection with special regard to 'vanishing bile duct syndrome'. Retransplantation may be considered in individual cases. In patients with hepatic graft insufficiency, nutritional guidelines should be followed in analogy to liver cirrhosis (11).

\section{FUTURE DIRECTIONS}

The benefit of specific nutrients (such as immuneenhancing substrates) for patients awaiting liver transplantation has to be clinically investigated. Focusing on the short term nutrition of the organ donor with anti-inflammatory substrates (eg, glycine or antioxidants) might decrease preservation and reperfusion injury (31). Better understanding of the metabolism of the grafted liver and the impact of appropriate substrate supplements in the early postoperative 
period might also help to improve outcome (32). The routine use of perioperative immunomodulating nutritional supplements might diminish systemic inflammatory response syndrome (33), morbidity (34) and even mortality. However, possible interaction with immunosuppressive agents cannot be completely excluded. Alexander et al (35) recently showed in rats that immunonutrition including arginine, omega-3-fatty acids and ribonucleotides after heart transplantations might induce oral graft tolerance. It is hypothesized that arginine induces a shift from cytotoxic $\mathrm{T}$-cells

\section{REFERENCES}

1. Shaw BW Jr, Wood RP, Gordon RD, Iwatsuki S, Gillquist WP, Starzl TE. Influence of selected patient variables and operative blood loss on six-month survival following liver transplantation. Semin Liver Dis 1985;5:385-93.

2. Müller MJ, Lautz HU, Plogmann B, Bürger M, Körber J, Schmidt FW. Energy expenditure and substrate oxidation in patients with cirrhosis: the impact of cause, clinical staging and nutritional state. Hepatology 1992;15:782-94.

3. Moukarzel AA, Najm I, Vargas J, McDiarmid SV, Busuttil RW, Ament ME. Effect of nutritional status on outcome of orthotopic liver transplantation in pediatric patients. Transplant Proc 1990;22:1560-3.

4. Selberg O, Boettcher J, Tusch G, Pichlmayr R, Henkel E, Müller MJ. Identification of high- and low-risk patients before liver transplantation: a prospective cohort study of nutrional and metabolic parameters in 150 patients. Hepatology 1997;25:652-7.

5. Roggero P, Cataliotti E, Ulla L, et al. Factors influencing malnutrition in children waiting for liver transplants. Am J Clin Nutr 1997;65:1852-7.

6. Harrison J, McKiernan J, Neuberger JM. A prospective study on the effect of recipient nutritional status on outcome in liver transplantation. Transpl Int 1997;10:369-74.

7. Pikul J, Sharpe MD, Lowndes R, Ghent CN. Degree of preoperative malnutrition is predictive of postoperative morbidity and mortality in liver transplant recipients. Transplantation 1994;57:469-72.

8. Akerman PA, Jenkins RL, Bistrian BR. Preoperative nutrition assessment in liver transplantation. Nutrition 1993;9:350-6.

9. DiCecco SR, Wieners EJ, Wiesner RH, Southorn PA, Plevak DJ, Krom RA. Assessment of nutritional status of patients with end-stage liver disease undergoing liver transplantation. Mayo Clin Proc 1989;64:95-102.

10. Weimann A, Kuse ER, Bechstein WO, Neuberger JM, Plauth M, Pichmayr R. Perioperative parenteral and enteral nutrition for patients undergoing orthotopic liver transplantation. Results of a questionnaire from 16 European transplant units. Transpl Int 1998;11(Suppl 1):289-91.

11. Plauth M, Merli M, Kondrup J, Weimann A, Ferenci P, Müller MJ. ESPEN guidelines for nutrition in liver disease and transplantation. Clin Nutr 1997;16:43-55.

12. Jeejeebhoy KN, Detsky AS, Baker JP. Assessment of nutritional status. JPEN J Parenter Enteral Nutr 1990;14(Suppl 5):193S-6S.

13. Hasse J, Strong S, Gorman MA, Liepa G. Subjective global assessment: alternative nutrition-assessment technique for liver-transplant candidates. Nutrition 1993;9:339-43.

14. Chin SE, Shepherd RW, Thomas BJ, et al. Nutritional support in children with end-stage liver disease: A randomized crossover trial of a branched-chain amino acid supplement. Am J Clin Nutr 1992;56:158-63.

15. Ozaki N, Ringe B, Gubernatis G, et al. Changes in energy substrates in relation to arterial ketone body ratio after human orthotopic liver transplantation. Surgery 1993;113:403-9.

16. Miki C, Iriyama K, Mirza DF, et al. Postperfusion energy metabolism of steatotic graft and its relation to early graft viability following liver transplantation. Dig Dis Sci 1998;43:74-9.

17. Reilly J, Mehta R, Teperman L, et al. Nutritional support after liver transplantation: a randomized prospective study. JPEN J Parenter Enteral Nutr 1990;14:386-91.

18. Wicks C, Somasundaram S, Bjarnason I, et al. Comparison of enteral feeding and total parenteral nutrition after liver transplantation. Lancet 1994;344:837-40.

19. Hasse JM, Blue LS, Liepa GU, et al. Early enteral nutrition support in to a downregulation of immune response and subsequent graft acceptance. With regard to immunosuppression, experimental data suggest that prevention of cyclosporine-induced nephrotoxicity might be possible by supplementation of glycine (36).

To elucidate these fascinating interactions between nutrition and transplant immunology, and to improve the perioperative care and outcome of patients undergoing liver transplantation, more well-designed, prospective metabolic and nutritional intervention studies are required.

patients undergoing liver transplantation. JPEN J Parenter Enteral Nutr 1995;19:437-43.

20. Pescovitz MD, Mehta PL, Leapman SB, Milgrom ML, Jindal RM, Filo RS. Tube jejunostomy in liver transplant patients. Surgery 1995;117:642-7.

21. Plevak DJ, DiCecco SR, Wiesner RH, et al. Nutritional support for liver transplantation: identifying caloric and protein requirements. Mayo Clin Proc 1994;69:225-30.

22. Kuse ER, Kemnitz J, Kotzerke J, et al. Fat emulsions in parenteral nutrition after liver transplantation: the recovery of the allografts RES function and histological observations. Clin Nutr 1990;9:331-6.

23. Delafosse B, Viale JP, Pachiaudi C, et al. Long-and medium-chain triglycerides during parenteral nutrition in critically ill patients. Am J Physiol 1997;272:E550-5.

24. Lundbom N, Laurila O, Laurila S. Central pontine myelinolysis after correction of chronic hyponatraemia. Lancet 1993;342:247-8.

25. McDiarmid SV, Colonna JO II, Shaked A, Ament ME, Busuttil RW. A comparison of renal function in cyclosporine- and FK-506-treated patients after primary orthotopic liver transplantation. Transplantation 1993;56:847-53.

26. Swart GR, Metselaar HJ, Hesselink EJ, van den Berg JWO. Whole body protein turnover rates and body composition before and after liver transplantation. In: Capocaccia L, Merli M, Riggio O, eds. Advances in Hepatic Encephalopathy and Metabolic Nitrogen Exchange. Boca Raton: CRC Press, 1995:76-80.

27. Müller MJ, Loyal S, Schwarze M, Lobers J, Selberg O, Ringe B. Resting energy expenditure and nutritional state in patients with liver cirrhosis before and after liver transplantation. Clin Nutr 1994;13:145-52.

28. Golling M, Lehmann T, Senninger N, Herfarth C, Otto G. Tacrolimus reduction improves glucose metabolism and insulin secretion after liver transplantation. Transplant Proc 1996;28:3180-2.

29. Munoz SJ, Deems RO, Moritz MJ, Martin P, Jarrell BE, Maddrey WC. Hyperlipidemia and obesity after orthotopic liver transplantation. Transplant Proc 1991;23:1480-3.

30. Palmer M, Schaffner F, Thung SN. Excessive weight gain after liver transplantation. Transplantation 1991;51:797-800.

31. Zhong Z, Jones S, Thurman RG. Glycine minimizes reperfusion injury in a low-flow reflow liver perfusion model in the rat. Am J Physiol 1996;270:G6332-8.

32. Ishikawa T, Yagi T, Ishine N, et al. Energy metabolism of the grafted liver and influence of preretrieval feeding process on swine orthotopic liver transplantation. Transplant Proc 1997;29:397-9.

33. Weimann A, Bastian L, Bischoff WE, et al. Influence of arginine, omega-3-fatty acids and nucleotide-supplemented enteral support on systemic inflammatory response syndrome and multiple organ failure in patients after severe trauma. Nutrition 1998;14:165-72.

34. Beal RJ, Bryg DJ, Bihari DJ. Immunonutrition in the critically ill. A systematic review of clinical outcome. Crit Care Med 1999;27:2799-2805.

35. Alexander JW, Levy A, Custer D, et al. Arginine, fish oil, and donor-specific transfusions independently improve cardiac allograft survival in rats given subtherapeutic doses of cyclosporin. JPEN J Parenter Enteral Nutr 1998;22:152-5.

36. Thurman RG, Zhong Z, von Frankenberg M, Stachlewitz RF, Bunzendahl H. Prevention of cyclosporine-induced nephrotoxicity with dietary glycine. Transplantation 1997;63:1661-7. 


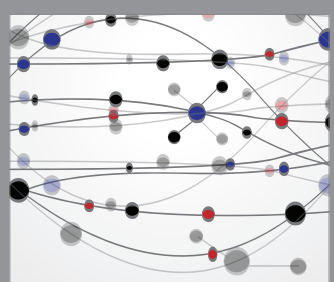

The Scientific World Journal
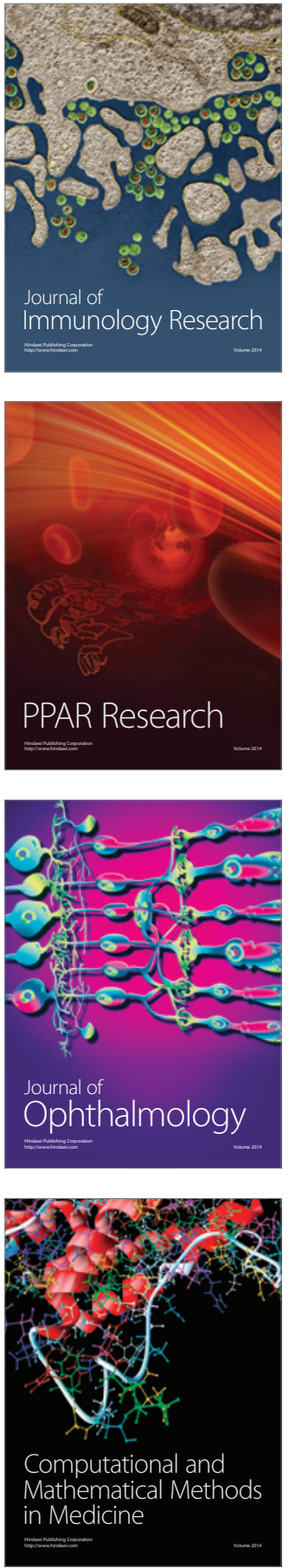

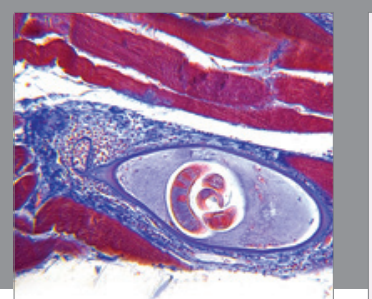

Gastroenterology Research and Practice

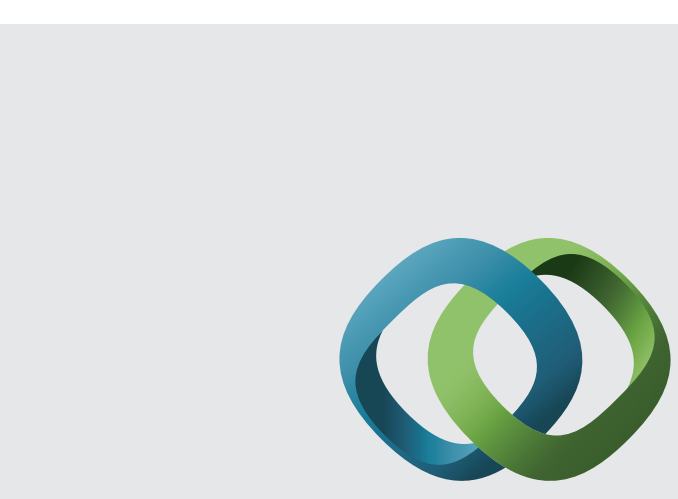

\section{Hindawi}

Submit your manuscripts at

http://www.hindawi.com
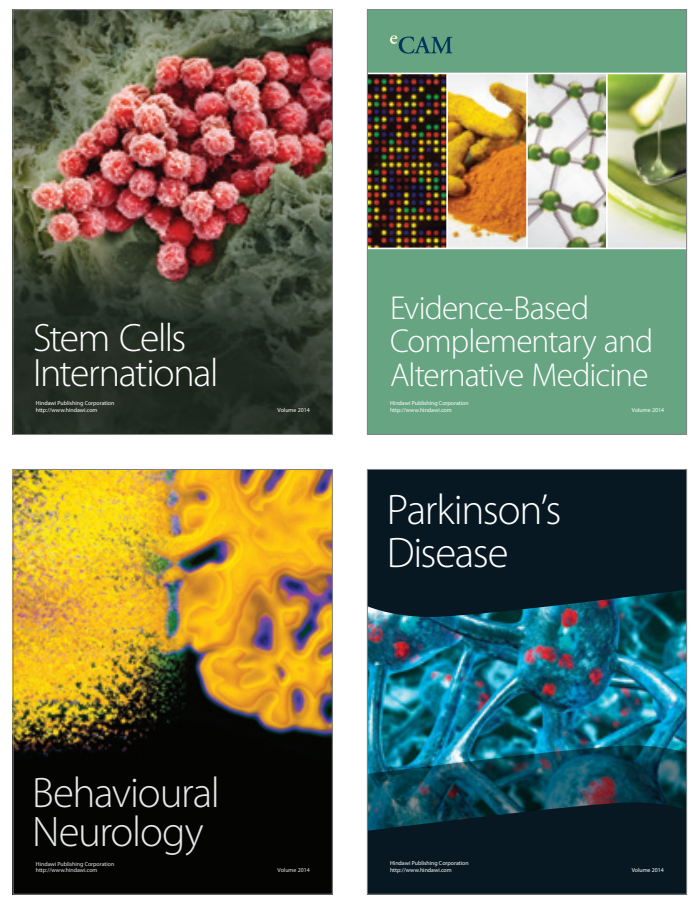
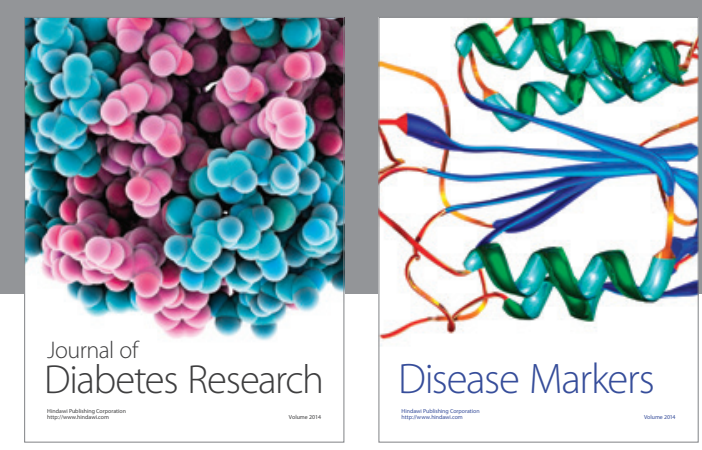

Disease Markers
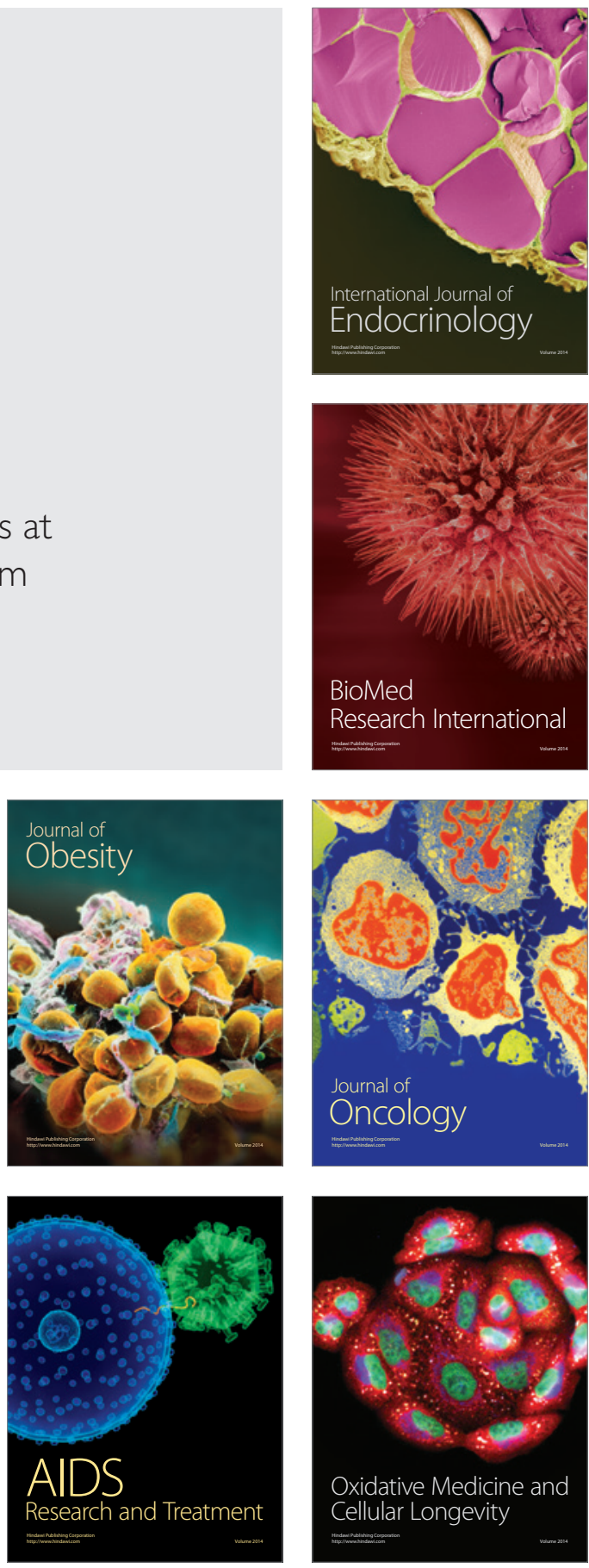